\title{
Eksistensi Tarekat Junaidi Al-Baghdadi Terhadap Pembinaan Masyarakat Islam di Majelis Darul Ikhlas Kota Palangka Raya
}

\author{
Nadiya Febrianti a,1,*, Dr. H. Abubakar H.M., M. Ag ${ }^{\text {b,c, }, 2}$, Muhammad Husni, M. Hum ${ }^{\text {b,3 }}$ \\ a,b,cInstitut Agama Islam Negeri Palangka Raya, Palangka Raya 73112, Indonesia \\ Inadiyafebrianti@gmail.com
}

Article history:

Received : 2019-10-31

Revised : 2019-12-24

Accepted : 2019-12-25

Keywords:

Tariqa,

Junaidi Al-Baghdadi,

Existence,

Majlis of Darul Ikhlas

Kata kunci:

Tarekat,

Junaidi Al-Baghdadi,

Eksistensi,

Majelis Darul Ikhlas.
This study discusses the existence of the Junaidi Al-Baghdadi Tarekat in Palangka Raya. Its existence indicates the teaching of Islam named Darul Ikhlas. There are three main issues raised in this study: first, to find out the ins and outs of the Junaidi Al-Baghdadi tariqah. Second, how is the model of teaching, and third, how the existence of the Junaidi Al-Baghdadi tarekat so that it can survive. The purposes of this research are to find out the system of teaching and the existence of its development in Palangka Raya Town. The research method used is a historical approach in the form of qualitative field research studies with literature review techniques and data collection is done through observation, documentation, and interviews. The results showed that the development of the Junaidi Al-Baghdadi tariqa, in terms of quantity, one of which was the establishment of the Majlis Taklim Darul Ikhlas, which showed the development achieved with a simple guidance system. The contribution made by the Junaidi AlBaghdadi Tarekat can be seen in terms of worship and social affairs. Thus, this Tarekat is facing progress and able to maintain its existence.

\section{ABSTRAK}

Penelitian ini membahas tentang eksistensi tarekat Junaidi AlBaghdadi di Palangka Raya, keberadaannya menunjukkan adanya pembinaan majelis bernama Darul Ikhlas. Pokok masalah yang diangkat dalam penelitian ini ada tiga yaitu pertama, untuk mengetahui seluk beluk tarekat Junaidi Al-Baghdadi kedua, bagaimana sistem pembinaannya dan ketiga, bagaimana eksistensi tarekat Junaidi Al-Baghdadi sehingga dapat bertahan. Tujuan dan manfaat penelitian ini adalah untuk, mengetahui sistem pembinaan dan eksistensi perkembangannya di kota Palangka Raya. Metode penelitian yang digunakan adalah pendekatan historis membahas dalam bentuk kualitatif studi penelitian lapangan dengan teknik kajian pustaka dan pengumpulan data lapangan melalui pengamatan, dokumentasi, dan wawancara. Hasil penelitian menunjukkan bahwa adanya perkembangan tarekat Junaidi Al-Baghdadi, dari segi kuantitas salah satunya adalah pendirian Majelis Darul Ikhlas yang menunjukkan adanya perkembangan yang dicapai dengan sistem pembinaan yang sederhana. Kontribusi yang diberikan oleh tarekat Junaidi Al-Baghdadi terlihat dari segi ibadah dan sosial. Dengan demikian, tarekat ini mengalami kemajuan dan mampu mempertahankan eksistensinya. 


\section{Pendahuluan}

Masuknya Islam ke Nusantara terjadi pada abad ke-1 Hijriyah atau abad ke-7 Masehi.(42) Suatu kenyataan bahwa kedatangan Islam ke Indonesia dilakukan secara damai.(12) Penyebaran Islam di Indonesia mampu menjalar dengan cepat yang dilakukan melalui beberapa jalur seperti perdagangan, perkawinan, kesenian, dakwah, pendidikan, dan tasawuf. Melalui tahapan-tahapan itulah Islam berangsur-angsur menyebar.(40) Jalur kontribusi terbesar penyebaran Islam di Indonesia melalui metode perdagangan, namun ada salah satu jalur yang juga berperan dalam masuknya Islam di Indonesia yaitu melalui tasawuf. Perlu kita ketahui sebelum Islam datang, masyarakat Nusantara mengenal berbagai paham tentang konsep Tuhan seperti Animisme, Dinamisme, Buddhaisme, dan Hinduisme.(14) Dengan pendekatan tasawuf ini usaha dakwah berhasil menarik masyarakat untuk memeluk agama Islam, orang yang mendalami ilmu tasawuf disebut dengan sufi sementara tasawuf tidak lepas dari tarekat.

Tarekat dalam bahasa arab yang berarti jalan, keadaan, aliran dalam garis pada sesuatu.(25) Tarekat yang pada awalnya hanyalah dimaksudkan sebagai metode, cara, dan jalan yang ditempuh seorang sufi menuju pencapaian spiritual tertinggi, pensucian diri atau jiwa, yaitu dalam bentuk intensifikasi dzikrAllah, berkembang secara sosiologis menjadi sebuah institusi sosial-keagamaan yang memiliki ikatan keanggotaan yang sangat kuat.(32) Tarekat melancarkan gerakan pembaruan di Nusantara sepanjang abad ke-17 dan abad ke-18 M, gerakan pembaruan itu berupa bentuk tasawuf yang dikembangkan yang dikenal dengan istilah neo-sufisme yang berbeda dari tasawuf falsafi. Neo-sufisme tersebut memiliki ciri seperti patuh terhadap syariah, serta menganjurkan aktivisme dan menolak sikap pasif terhadap dunia. (13)

Penyebaran Islam melalui jalur tarekat sebagai organisasi dari tasawuf ini merambat ke berbagai daerah di Nusantara dan berkembang dengan beberapa ajaran. Terdapat banyak sekali tarekat yang berkembang di Nusantara di antaranya adalah tarekat Shadhiliyah (47), tarekat Muqtadiriyah(28), tarekat Qodariyah dan
Naqsabandiyah(48) , tarekat. Sammaniyah (46), dan salah satu ajaran tarekat itu adalah tarekat Junaidiyah (26) yang diambil dari nama Junaidi Al-Baghdadi sebagai pendirinya. Inilah tarekat yang penulis bahas dalam penelitian ini. Fenomena dalam penyebaran Islam melalui jalur tasawuf dan tarekat sebagai metodenya yang kemudian berkembang menjadi suatu ikatan lembaga perkumpulan, maka peneliti tertarik untuk menelusuri bagaimana sejarah tarekat Junaidi Al-Baghdadi dan bagaimana tarekat ini dalam pembinaan nya kepada masyarakat Islam kota Palangka Raya dalam suatu majelis bernama Majelis Darul Ikhlas sehingga dapat mempertahankan eksistensi perkembangan nya di kota Palangka Raya.

Terkait penelitian yang dilakukan, sebelumnya sudah ada penelitian yang berhubungan dengan tarekat Junaidi AlBaghdadi di antaranya penelitian Nor Ipansyah yang membahas dan berfokus kepada tarekat Junaidi Al-Bagdhadi dalam perkembangannya di Kalimantan Selatan. Selain itu, penelitian mengenai tarekat Junaidi Al-Baghdadi juga sudah dilakukan oleh Husnul Khatimah, hasil dari penelitiannya lebih banyak berfokus membahas bentuk aktivitas dakwah dari tarekat Junaidi AlBaghdadi dan sedikit membahas masuknya tarekat tersebut ke Palangka Raya. Pada kedua penelitian terdahulu yang berhubungan dengan penelitian ini dapat disimpulkan berbeda baik dari segi konteks dan substansinya.

Terlepas dari banyaknya ajaran tarekat yang tersebar, maka tarekat Junaidi AlBaghdadi di kota Palangka Raya berhasil mempertahankan eksistensinya sehingga mengalami perkembangan dalam bidang ibadah dan sosial. Oleh karena mengingat penulisan untuk tarekat Junaidi Al-Baghdadi terasa masih kurang terkhusus di kota Palangka Raya terkait tarekat ini tidak sepopuler seperti tarekat Naqsabandiyah, Qadariyah, dan Sammaniyah maka dilakukanlah penelitian ini.

Kalimantan merupakan pulau terbesar kedua di Indonesia setelah Papua dengan penduduk lokalnya yang disebut dengan suku Dayak.(17) Dengan wilayah yang terhitung luas tersebut keberadaan dari tarekat Junaidi Al-Baghdadi di kota Palangka Raya dapat 
berkembang dan melanjutkan eksistensinya ke daerah lain.

Adapun strategi yang digunakan tarekat Junaidi Al-Baghdadi dalam mempertahankan eksistensinya yaitu melalui pendekatan sosial di antaranya membangun rasa saling simpati antara jamaah yang dapat dilihat saat salah satu jamaah pada Majelis Darul Ikhlas mengalami musibah.

Teori selanjutnya yaitu interaksi sosial, mengandung makna tentang kontak secara timbal balik atau interstimulasi dan respon antara individu-individu dan kelompokkelompok.(41) Aspek-aspek interaksi sosial yaitu adanya hubungan, adanya individu, adanya tujuan, adanya hubungan dengan struktur dan fungsi kelompok.(37) Dalam hal ini berarti bahwa adanya interaksi sosial yang dilakukan antar jamaah tarekat Junaidi AlBaghdadi pada majelis Darul Ikhlas. Interaksi tersebut dapat juga terjalin antara jamaah Majelis Darul Ikhlas kepada orang luar jamaah sehingga hal ini dapat membuat suatu ketertarikan untuk mengikuti Majelis Darul Ikhlas ini.

Teori solidaritas sosial ini digunakan untuk mengkaji bagaimana solidaritas yang terjalin di antara penganut tarekat Junaidi AlBaghdadi. Durkheim menyatakan bahwa solidaritas sosial merupakan suatu keadaan hubungan antara individu dan atau kelompok yang didasarkan pada perasaan moral dan kepercayaan yang dianut bersama dan diperkuat dengan pengalaman emosional bersama.(19) Teori ini dapat diukur seberapa solidaritasnya para jamaah dalam Majelis Darul Ikhlas. Teori ini berkaitan dengan teori interaksi sosial, karena adanya interaksi yang dilakukan dalam Majelis Darul Ikhlas ini maka akan membangun solidaritas yang kuat, sehingga dapat disimpulkan dari temuan di lapangan para jamaah Majelis Darul Ikhlas solid sebagai bukti bahwa para jamaah dengan suka rela memberikan infak untuk terselenggaranya pembelajaran.

\section{Review Tinjauan Pustaka}

Penelitian terdahulu atau tinjauan pustaka ini menjadi salah satu acuan penulis dalam melakukan penelitian sehingga penulisan dapat memperkaya teori yang digunakan dalam mengkaji penelitian yang dilakukan. Dari penelitian terdahulu, penulis tidak menemukan penelitian dengan judul yang sama seperti judul penelitian penulis. Namun penulis mengangkat beberapa penelitian sebagai referensi dalam memperkaya bahan kajian pada penelitian penulis. Berikut merupakan penelitian terdahulu berupa tulisan ilmiah dan skripsi di beberapa jurnal terkait dengan penelitian yang dilakukan penulis.

1. Nor Ipansyah, 2011. Tarekat Junaidiyah di Kalimantan Selatan, Portal Garuda: Jurnal Al-Banjari, Vol. 10 No. 1, Banjarmasin: IAIN Antasari Banjarmasin, yang membahas dan berfokus hanya kepada tarekat Junaidi Al-Bagdhadi dalam perkembangannya di Kalimantan Selatan.

2. Husnul Khotimah, 2005. Aktivitas Dakwah Islam Tarekat Junaidi AlBaghdadi Palangka Raya, Skripsi S1, Palangka Raya: Sekolah Tinggi Agama Islam Palangka Raya Jurusan Dakwah Program Studi Komunikasi dan Penyiaran Islam, tulisannya mempunyai fokus dalam bentuk aktivitas dakwah dari tarekat Junaidi Al-Baghdadi dan sedikit membahas masuknya tarekat tersebut ke Palangka Raya.

3. Subaidi, 2014. Teori Ekonomi Junaidi Al-Baghdadi, At-Tahdzi: Jurnal Studi Islam dan Muamalah, Vol. 02 No.1, Jombang: Institut Agama Islam Ibrahimy Sukorejo Situbondo, membahas mengenai teori ekonomi yang dilihat dari sudut pandang tarekat Junaidi AlBaghdadi

4. Aditya Pratama, 2015. Tauhid Perspektif Junayd Al-Baghdadi dalam Kitabkitab Manual Klasik Tasawuf, Skripsi thesis: Repository UIN SUSKA, Universitas Islam Negeri Sultan Syarif Kasim Riau, tulisan Aditya Pratama membahas tauhid dalam perspektif tarekat Junaidi AlBaghdadi dalam kitab manual klasik tasawuf.

5. Muhammad Achsin, 2017. Tauhid Sufistik (Konsep Tauhid Junayd AlBaghdadi), Skripsi: Digital Library Universitas Islam Negeri Sunan Ampel Surabaya, tulisan ini membahas konsep tauhid dari segi sufistiknya.

Perbedaan antara kelima tulisan tersebut dengan penelitian yang dilakukan ini terletak pada fokus penelitian maupun konteks yang 
dibahas. Sementara penelitian ini fokus dengan bagaimana eksistensi tarekat Junaidi Al-Baghdadi dari awal perkembangannya di Palangka Raya hingga saat ini dan pembinaannya terhadap masyarakat melalui Majelis yang bernama Majelis Darul Ikhlas Palangka Raya sehingga adanya kontribusi yang diberikan untuk jamaah dan dalam kehidupan bermasyarakat.

\section{Metodologi Penelitian}

Penelitian ini menggunakan suatu pendekatan kualitatif (39) dengan jenis penelitian field research (penelitian lapangan) yang bersifat deskriptif. Di sini peneliti mengumpulkan data melalui wawancara langsung dengan beberapa jamaah majelis taklim dan mewawancarai unsur pembina atau guru yang melaksanakan dakwah kepada kaum muslimin. Penelitian yang menggunakan pengumpulan data lapangan ini dilengkapi juga dengan library research (kajian pustaka) yang memiliki keterkaitan dengan penelitian ini. Sumber-sumber penunjang lain di antaranya observations (pengamatan) awal sebanyak dua kali, documents (dokumen-dokumen) berupa foto, dokumen surat atau sertifikat ijazah tarekat Junaidi Al-Baghdadi milik jamaah Majelis Darul Ikhlas, buku-buku yang diajarkan pada tarekat Junaidi Al-Baghdadi di Majelis Darul Ikhlas, interviews (wawancara) (16) kepada beberapa narasumber sesuai dengan karakteristik yang telah ditentukan seperti umur narasumber.

Adapun bahan atau bukti temuan lapangan dapat menggunakan metode sebagai berikut, pertama tahap heuristik berupa penghimpunan jejak dan sumber penelitian. Tahap kedua, kritik sumber yaitu usaha menyelidiki jejak sumber-sumber sejarah yang baik bentuknya maupun isinya dari segi asli atau tidaknya sumber tersebut hingga layak atau tidaknya dipakai. Tahap ketiga, interpretasi yaitu menetapkan makna yang saling berhubungan dari fakta yang diperoleh, pada tahap ini diberikan pula penjelasan dan tafsiran terhadap sumber sejarah yang lolos dari kritik tadi. Selanjutnya apabila data atau bukti tadi telah melalui tahap kritik maka akan dijelaskan apakah bukti tersebut merupakan temuan baru atau tidak. Tahap keempat, historiografi yaitu kegiatan untuk menyusun secara sintesis dari hasil penafsiran atas fakta- fakta sejarah yang akan ditulis agar menjadi suatu kisah yang selaras.

\section{Hasil dan Diskusi}

A. Sejarah Berdirinya Tarekat Junaidi AlBaghdadi di Palangka Raya.

Tarekat Junadi Al-Baghdadi dikaitkan dengan nama Junaidi AlBaghdadi yang bernama asli Abu al-Qasim al-Junaid bin Muhammad al-Junaid alKhazzaz al-Qawawiri, dilahirkan di Baghdad namun sebagian besar orang tahu bahwa dia memiliki nenek moyang yang berasal dari kota Nihawand, Provinsi Jibal, Persia.

Junaidi Al-Baghdadi memang berbeda, jarak yang dijaganya dari poros tasawuf falsafi membuatnya terhindar dari nasib tragis seperti yang dialami Abu mansyur al-Hallaj (w.309/922). Tidak hanya itu kelenturan bahasa dan kejelasan tutur katanya bahkan lebih dicintai dari gaya ketasawufan Abu Yazid al-Bustami (w. 261/857).(1) Tidak heran kalau kemudian Ibnu Taimiyah dapat menerima pemikiran Junaidi Al-Baghdadi. Itu dibuktikan dengan apresiasinya terhadap prinsip tasawuf Junaidi Al-Baghdadi yang tersimpul dalam statemennya "Ilmu ini mengacu pada al-Qur'an dan Sunnah. Barang siapa yang tidak membaca alQur'an dan menulis Hadis maka tidak pantas untuk berkata-kata tentang keilmuan kami".(10) Hingga Junaidi AlBaghdadi memiliki banyak murid dan pengikut, dan terhadap kecintaannya dengan tasawuf maka lahir dan berkembanglah tarekat yang sekarang kita kenal dengan tarekat Junaidiyah atau tarekat Junaidi Al-Baghdadi. Karya Junaidi Al-Baghdadi terdiri dari karyakarya yang masih dapat dibaca sekitar 30, karya-karya yang hilang sekitar 6 , dan karya yang dianggap sebagai milik Junaidi Al-Baghdadi sekitar 5.

Mengulas mengenai salah satu tarekat yang ada di Palangka Raya adalah tarekat Junaidi Al-Baghdadi. Penyebaran tarekat Junaidi Al-Baghdai telah sampai ke pulau Kalimantan dengan wilayah pertumbuhan pertama adalah Desa Banua Hanyar kecamatan Sungai Pandan Alabio kabupaten Hulu Sungai Utara yang dibawa 
dari tanah suci Mekkah oleh K.H Kaspul Anwar Firdaus al-Banjari pada tahun 1954 setelah menerima bai'at dan belajar langsung sekitar kurang lebih 25 tahun (sejak tahun 1929) untuk memperdalam ilmu tarekat tersebut dari satu mursyid ke mursyid lainnya, di antaranya adalah Syeikh Said Umar Ba Junaidi.(24) Dalam mengembangkan ajaran tarekat tersebut, K.H Kaspul Anwar melakukan dengan tekun maka pada akhirnya banyak masyarakat yang menjadi muridnya dan di antaranya adalah Alm. Syeikh K.H Muhammad Qurtubi Khalid (wafat tanggal 15 Juli 2002) makamnya sekarang berada di jalan Surung kelurahan Sabaru kecamatan Sebangau Palangka Raya.

Menjelang wafat (14 Februari 1975) K.H Kaspul Anwar memberi amanat kepada K.H Muhammad Qurtubi Khalid untuk menyebarkan ajaran tarekat Junaidi Al-Baghdadi, yang mana sebelumnya K.H Muhammad Qurtubi Khalid sudah menerima ijazah tarekat tersebut pada tahun 1960. Akhirnya tahun 1975 beliau mulai melaksanakan mursyidnya dengan meneruskan untuk mengajar dan mengembangkan ilmu fiqih, tauhid, dan tasawuf secara bertarekat kepada muridmuridnya. (24)

Tahun 1976, K.H Muhammad Qurtbi Khalid membawa ajaran tarekat Junaidi Al-Baghdadi ke Kalimantan Tengah, khususnya Palangka Raya. Setelah kurang lebih dua tahun menyebarkannya, pada tahun 1978 beliau berangkat ke Mekkah untuk belajar ilmu tasawuf kepada Syeikh H. Abdul Karim selama 7 bulan sekaligus untuk menunaikan ibadah haji. Saat pulang ke kampung halamannya di Desa Cempaka/Penyiuran kecamatan Amuntai Selatan beliau juga menyebarkannya disana dan terkenal sampai ke kabupaten Tabalong, tidak lama kemudian beliau kembali ke Palangka Raya dan mengembangkan ajaran tarekat ini. Untuk mensosialisasikan keberadaannya agar lebih terkenal maka atas inisiatif dari K.H Muhammad Qurtubi Khalid dibentuklah organisasinya yang diberi nama Tarekat Junaidi Al-Baghdadi dengan pimpinan tertinggi (khalifah)nya adalah beliau sendiri pada tanggal 11 Juli 1998 di Palangka Raya.(24) Kesimpulan dapat diambil adalah persebaran Islam dan bahkan persebaran tarekat pun berasal dari Kalimantan Selatan dengan mengikuti aliran-aliran sehingga sampailah ke Kalimantan Tengah.

B. Sistem Pembinaan Tarekat Junaidi AlBaghdadi di Kota Palangka Raya

Sebuah kelompok belajar secara formal maupun non-formal tentu mempunyai suatu sistem pembinaan yang biasa disebut dengan metode. Dalam Kamus Bahasa Indonesia Kontemporer disebutkan bahwa metode merupakan cara yang teratur dan ilmiah dalam mencapai maksud untuk memperoleh ilmu atau juga merupakan cara mendekati, mengamati, menganalisis, dan menjelaskan suatu fenomena dengan menggunakan landasan teori.(34) Sistem pembinaan yang digunakan tarekat Junaidi Al-Baghdadi pada Majelis Darul Ikhlas di Palangka Raya terbagi menjadi tiga yaitu klasikan tradisional, ceramah tanya jawab serta materi dan amalan. Ketiga sistem pembinaan (metode) tersebut akan dibahas point per-point.

1. Klasikal Tradisional

Metode klasikal tradisional merupakan salah satu metode yang dipakai sudah sejak lama seiring adanya perkembangan pesantren semenjak masa-masa permulaan kedatangan Islam di Indonesia.(4) Model mengajar menggunakan klasikal tradisional seperti ini digunakan oleh guru atau ustadz tarekat Junaidi AlBaghdadi di Palangka Raya terkhususnya pada Majelis Darul Ikhlas, yang mana model di sini dapat diartikan sebagai pola dari sesuatu yang akan dibuat atau dihasilkan. Kemudian mengajar diartikan sebagai suatu aktivitas mengorganisasi dan mengatur lingkungan sebaik-baiknya dan menghubungkan dengan peserta didik, sehingga terjadi proses pembelajaran.(35)

Model pembelajaran klasikal sendiri adalah kegiatan penyampaian pelajaran kepada sejumlah peserta didik atau kepada jamaah, yang biasanya dilakukan oleh pendidik dengan berceramah di kelas. Pembelajaran 
klasikal mencerminkan kemampuan utama pendidik, karena pembelajaran klasikal ini merupakan kegiatan pembelajaran yang tergolong efisien. Pembelajaran secara klasikal ini memberi arti bahwa seorang pendidik melakukan dua kegiatan sekaligus yaitu mengelola kelas dan mengelola pembelajaran.(33) Menurut penulis, dari kalimat-kalimat sebelumnya dapat ditarik kesimpulan bahwa belajar klasikal tidak harus memberikan spekulasi mengenai tempat seperti kelas-kelas, karena klasikal tidak hanya dari sudut pandang tempat yang kita lihat, akan tetapi bisa dari cara penyampaiannya.

Belajar secara klasikal cenderung menempatkan peserta didik dalam posisi pasif, sebagai penerima bahan pelajaran. Upaya mengaktifkan peserta didik dapat menggunakan metode tanya jawab, diskusi, demonstrasi yang dalam artian memperagakan, dan lainlain.(43) Tarekat Junaidi Al-Baghdadi di Palangka Raya khususnya Majelis Darul Ikhlas ini menggunakan model pembelajaran klasikal tradisional yang pada awalnya pembelajaran yang diberikan oleh guru kepada jamaah bertempat di rumah Kai $H$. Suryani selaku pendiri Majelis Darul Ikhlas ini, kemudian sedikit demi sedikit dibangunlah sebuah Masjid bernama Sirajul Jama'ah untuk menjadi wadah belajar mengajar.(23) Jadi, dapat disimpulkan bahwa hasil dari model pembelajaran berupa klasikal tradisional yang dipakai tarekat Junaidi Al-Baghdadi di Palangka Raya terkhusus Majelis Darul Ikhlas ini yaitu untuk membentuk jamaah yang lebih menguasai dan mengerti akan ilmu yang diajarkan karena ini juga menyangkut amalan dalam keseharian guna mendekatkan diri kepada Allah SWT.

\section{Ceramah Tanya Jawab}

Ceramah adalah penuturan bahan pelajaran secara lisan. Metode ini tidak senantiasa jelek bila penggunaannya betul-betul dipersiapkan dengan baik. Metode ini merupakan metode yang sering kita jumpai sehari-hari, terutama dalam proses belajar mengajar.(38) Perlu diperhatikan bahwa metode ceramah akan lebih efektif bila dipadukan dengan metode lain, misalnya tanya jawab, diskusi, atau latihan.

Dapat penulis simpulkan secara singkat pada metode ceramah tanya jawab ini adalah memberikan penjelasan pelajaran secara lisan kemudian apabila anak didik atau jamaah tidak mengerti akan materi pembahasan yang diberikan oleh seorang guru maka dapat dilanjutkan dengan metode tanya jawab untuk memperjelas materi pembahasan tersebut. Pada tarekat Junaidi AlBaghdadi di Palangka Raya khususnya Majelis Darul Ikhlas ini juga memakai metode ceramah tanya jawab, pada awalnya pengajar pada Majelis Darul Ikhlas tersebut bernama Guru Alm. Abdul Wahab dan sekarang digantikan oleh Guru H. Abdul Fatah.(23) Para guru tersebut juga biasa disebut dengan Badal, majelis Darul Ikhlas ini hanya mempunyai satu guru.

Menurut penulis dalam tenaga pengajar atau guru yang dipunyai Majelis Darul Ikhlas ini ada dampak positif dan negatifnya. Pertama, hanya mempunyai seorang guru akan terasa sulit dalam masalah waktu, salah satunya karena kesibukkan pribadi dari guru yang mengajar. Guru H. Abdul Fatah merupakan pengajar di Majelis Darul Ikhlas,selain itu dia juga seorang penceramah serta orang yang biasa diminta tolong oleh masyarakat untuk memandikan orang meninggal. Kedua, dampak positifnya materi akan mudah dipahami karena jamaah hanya mendengarkan dari satu orang guru. Dari kedua hal tersebut semuanya kembali lagi kepada aturan yang ada pada tarekat Junaidi Al-Baghdadi yang memberikan syarat untuk dapat mengajar (ilmunya sudah sampai).

Guru H. Abdul Fatah dalam memberikan materi yang akan dibahas dalam pertemuan dengan para jamaah menggunakan metode ceramah, kemudian apabila dalam penjelasannya 
masih belum dapat dipahami maka jamaah dapat melakukan tanya jawab kepada guru H. Abdul Fatah. Selain menjelaskan materi berupa dari kitab maka sesekali guru H. Abdul Fatah memberikan praktik langsung agar dalam penerapannya para jamaah tidak salah dalam mengamalkan ilmu.(20)

3. Materi dan Amalan

Pembelajaran secara sederhana dapat diartikan sebagai sebuah usaha mempengaruhi emosi, intelektual, dan spiritual seseorang agar mau belajar dengan kehendaknya sendiri. Pembelajaran berbeda dengan mengajar yang pada prinsipnya menggambarkan aktivitas guru, sedangkan pembelajaran menggambarkan aktivitas peserta didik.(3) Dalam pembelajaran maka tentu ada yang dinamakan materi yang akan disampaikan kepada murid atau jamaah.

Berhubungan dengan isi atau materi pelajaran yang merupakan komponen kedua dalam sistem pembelajaran. Dalam konteks tertentu, materi merupakan inti dalam proses pembelajaran. Artinya, sering terjadi dalam proses pembelajaran diartikan sebagai proses penyampaian materi. Materi pembelajaran atau materi ajar (instructional materials) adalah pengetahuan, sikap dan keterampilan yang harus dipelajari siswa dalam rangka mencapai standar kompetensi yang telah ditentukan. (45)

Tarekat Junaidi Al-Baghdadi di Palangka Raya khususnya Majelis Darul Ikhlas ini membahas materi yang beragam selain permasalahan tasawuf atau tarekat, akan tetapi juga membahas ilmu tauhid, fiqih, hakikat dan makrifat.(36)

Amaliyah tarekat Junaidi AlBaghdadi yang dikerjakan oleh jamaah ketika diajarkan di Majelis Darul Ikhlas yang pertama dzikir, yang secara etimologi Dzikir berasal dari kata dzakara artinya mengingat, memperhatikan, mengenang, mengambil pelajaran, mengenal atau mengerti dan mengingat.(8) Menurut
Chodjim bagi orang yang berdzikir berarti mencoba mengisi dan menuangi pikiran dan hatinya dengan kata-kata suci (5), seperti dalam setiap nafas kita wajib berdzikir mengingat Allah SWT, setiap detak jantung yang ada pada diri kita seakan-akan menyebut nama Allah.

Menurut Amin Syukur dzikir mempunyai manfaat yang besar terutama dalam dunia modern antara lain sebagai berikut:(9)

1. Dzikir memantapkan iman

2. Dzikir dapat menghindarkan dari bahaya

3. Dzikir sebagai terapi jiwa

4. Dzikir menumbuhkan energi akhlak

Manfaat tersebut juga telah disebutkan langsung di dalam Al Qur'an Q.S Al Ra'ad:

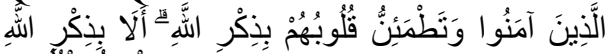

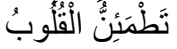

Artinya: (yaitu) orang-orang yang beriman dan hati mereka menjadi tenteram dengan mengingat Allah. Ingatlah, hanya dengan mengingat Allah-lah hati menjadi tentram.(Q.S. Al Ra'd: 28)

Sebelum dzikir dalam tarekat Junaidi Al-Baghdadi diajarkan talqin yaitu semacam pembuka bacaan berupa surah-surah pendek dan dzikirdengan niat pahala bacaan tersebut untuk silsilah tarekat Junaidi Al-Baghdadi. Dalam buku yang diajarkan tarekat Junaidi Al-Baghdadi pada Majelis Darul Ikhlas ini dzikir terbagi menjadi dua yaitu dzikir khafi dan dzikir akhfa, dilanjutkan dengan membaca asmaul husna, doa, dan tawajjuh mutlaq.

Adapun amaliyah untuk berwirid ada berbagai macam bacaan yang dipakai dalam wiridan, meski demikian yang terpokok biasanya terdiri dari tiga lafadz yaitu : Subhanallah, Alhamdulillah, dan Allahu Akbar. Seperti yang biasa dijumpai di masjidmasjid, sebelum mewiridkan ke tiga bacaan tersebut, ada bacaan awal sebagai muqaddimahnya dan ada bacaan akhir sebagai setelahnya.(2) 
Adapun wirid adalah amalan yang dikerjakan di dunia secara tetap dan tertib di dunia ini, juga berupa ibadah secara tertib, termasuk dzikir yang dikerjakan secara terus-menerus, tidak pernah ditinggalkan. Warid merupakan karunia Allah swt. kepada para hamba, berupa penjelasan, nurullah, kenikmatan merasakan ibadah, hidayah dan taufiq Allah, semuanya merupakan amalan batin yang kuat. Kenikmatan alwarid itu berkelanjutan hingga hari akhir. Antara Wirid dan Al-warid memiliki kaitan yang kuat. Apabila warid itu karunia dari Allah, maka wirid adalah ibadah yang tetap dan tertib.(18)

Amaliyah selanjutnya yaitu sholawat-sholawat dengan berupa syair sebagai peresapan diri untuk menuju lebih baik dan memperbaiki kesalahan yang telah dilakukan dengan beristigfar guna menggugurkan dosa, sebagaimana seperti dalil Al Qur'an dan hadist dari Rasulullah SAW seperti berikut:

Dalil Al Qur'an Q.S Nuh: 10-12:

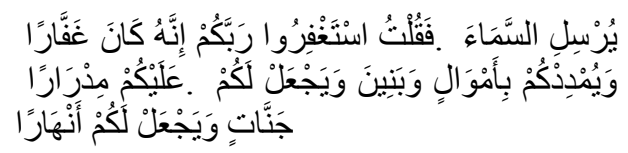

Artinya: Mohonlah ampun kepada Rabb kalian, sesungguhnya Dia adalah Maha Pengampun, niscaya Dia akan mengirimkan hujan kepadamu dengan lebat, dan membanyakkan harta dan anak-anakmu dan mengadakan untukmu kebun-kebun dan mengadakan (pula di dalamnya) untukmu sungaisungai. (QS.Nuh: 10-12) SAW:

Dan Hadist Nabi Muhammad

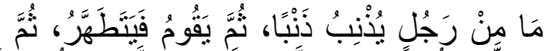

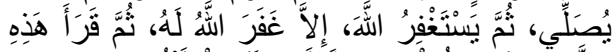

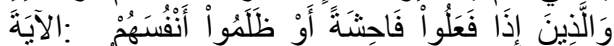

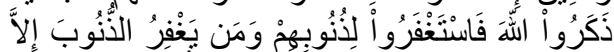

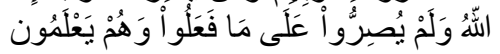

"Tidak ada satupun seorang hamba yang berbuat suatu dosa, kemudian berdiri untuk bersuci, kemudian melakukan sholat dan beristighfar untuk meminta ampun kepada Allah, kecuali Allah akan mengampuni dosanya. Kemudian Rasulullah Shallallahu 'alaihi wa
Sallam membaca surat Ali Imran, ayat: 135, yang artinya: " Dan (juga) orangorang yang apabila mengerjakan perbuatan keji atau menganiaya diri sendiri mereka ingat akan Allah, lalu memohon ampun terhadap dosa-dosa mereka dan siapa lagi yang dapat mengampuni dosa selain dari pada Allah? Dan mereka tidak meneruskan perbuatan kejinya itu, sedang mereka mengetahui". (Hadits Hasan Riwayat at-Tirmidzi no: 3009, Abu Daud, no: 1521)(6)

Sholawat yang biasa diamalkan pada Majelis Darul Ikhlas ini adalah berupa syair-syair habsyi, dan juga terdapat syair tarekat, sholawat lailatul qadar.

C. Pola Pembinaan Tarekat Junaidi AlBaghdadi

1. Pemahaman Jamaah Terhadap Tarekat Junaidi Al-Baghdadi

Pemahaman beberapa jamaah terhadap tarekat Junaidi Al-Baghdadi yang belajar di Majelis Darul Ikhlas ini yaitu pengamalan yang seimbang antara urusan dunia akan tetapi tidak melupakan urusan akhirat. Hal ini juga sejalan dengan Imam Junaidi AlBaghdadi yang dianggap bisa mempertemukan fikih dan tasawuf di saat keduanya tidak pernah mengalami titik temu. Sikap proporsional itu sejalan dengan pandangan NU mengenai tawasut (moderat), tawazun (seimbang), tasamuh (toleran), dan iktidal (adil). (27)

Secara sadar atau tidak sadar tarekat Junaidi Al-Baghdadi ini sejalan dengan pemikiran Al-Ghazali yang mengemukakan pemikirannya tentang fikih sufistik. Al-Ghazali adalah ulama besar yang sanggup menyusun kompromi antara syariat dan hakikat atau tasawuf menjadi bangunan baru yang cukup memuaskan kedua belah pihak, baik dari kalangan syar'i lebihlebih kalangan sufi. Al-Ghazali mengikat tasawuf dengan dalil-dali wahyu baik dari Al Qur'an maupun Hadits Nabi.(30) Bahwa fikih dan tasawuf ini tidak bisa dipisahkan, yakni fikih yang tidak hanya 
mengandalkan sifat lahiriyah, melainkan melibatkan sifat batiniyah dari setiap cabang ilmu termasuk fikih dapat digali dan dipadukan dengan tasawuf sebagai jalannya.

Dengan demikian, fiqh sufistik AlGhazali adalah fikih yang bernuansa lahir dan batin atau dengan kata lain moralitas dan hukum menjadi satu kesatuan yang tidak dapat pisahkan satu sama lainnya.(15) Mengikuti tarekat Junaidi Al-Baghdadi para jamaah merasakan kenikmatan berupa kenikmatan beribadah, dimana mereka yang mengikuti tarekat ini bertujuan untuk menyempurnakan ibadah secara lahir dan batin. Salah satu jamaah yang kurang lebih sudah dua puluh tahun mengikuti tarekat ini menyatakan bahwa salah satu dari menikmati ibadah dengan menyempurnakannya secara lahir batin misalnya shalatnya harus jiwa raga maka kita akan menemukan rahasia-rahasia Allah apabila kita benar-benar menikmati kekhusyukkannya.(21)

2. Kontribusi Tarekat Junaidi AlBaghdadi Terhadap Jamaah Majelis Darul Ikhlas

Kontribusi merupakan kata lain dari sumbangan, jadi bagaimana sumbangsih tarekat ini terhadap penganut dan kehidupan bermasyarakat. Kontribusi terhadap penganut seperti yang dirasakan oleh salah satu jamaah yang bernama $\mathrm{Hj}$. Norsehan seperti yang dituturkannya adalah seperti dalam hal beribadah menjadi lebih khusyuk karena diajarkan saat berdzikir dan mengerjakan amaliyah itu harus berfokus lahir dan batin menghadap Allah. Untuk kontribusi tarekat terhadap kehidupan bermasyarakat adalah dapat kita lihat dari nilai lebih yang diajarkan Imam Junaidi AlBaghdadi adalah menyeimbangkan antara ibadah mahdhah dengan ibadah sosial.

Artinya bahwa tarekat ini mengajarkan keseimbangan antara urusan ibadah dan sosial dalam bermasyarakat. Hal ini dibenarkan oleh salah satu jamaah majelis Darul Ikhlas bernama Armah, bahwa tidak ada yang merugikan mengikuti tarekat ini, karena adanya keseimbangan itu tadi. Mengikuti tarekat dapat menghindari perbuatan yang tercela baik secara lahir ataupun batin.(11)

Hal itu senada dengan apa yang dikatakan oleh Junaidi Al-Baghdadi itu sendiri. Imam Junaidi juga menyayangkan sikap naif sebagian kelompok sufi yang mengabaikan realitas dan aspek lahiriyah. Sebaliknya, ia juga menyayangkan sekelompok umat Islam yang hanya mengutamakan sisi lahiriyah melalui formalitas hukum fiqih dengan mengabaikan sisi batiniyah yang merupakan roh dari kehambaan manusia kepada Allah. (7)

Menurut sudut pandang penulis, apabila para remaja benar-benar ingin menekuni agama maka tidak salah untuk mengikuti tarekat, karena dengan pembersihan hati itu menjauhkan kita dari kenakalan remaja dan itu tentu menjadi kontribusi terbesar tarekat dalam membangun kembali moral generasi bangsa.

a. Kontribusi Bidang Ibadah

Kontribusi atau sumbangsih dari tarekat Junaidi Al-Baghdadi dalam bidang ibadah berupa mencari ketenangan serta kekhusyukan dalam urusan ibadah. Jika urusan kita dengan Allah Swt melalui beribadah sudah baik maka kemudian yang lainnya pun juga akan mengikuti, salah satunya terhindar dari perbuatan tercela.(22) Bagi remaja juga sebenarnya tidak salah mengikuti tarekat ini, karena banyak kebaikan yang diajarkan di dalamnya, dan hal itu dapat mencegah para remaja kepada penyimpangan sosial dan dapat mengurangi kenakalan remaja, oleh dikarenakan hari-hari mereka diisi dengan kegiatan yang positif. Untuk semakin meningkatkan spiritualitas menyalurkan sekaligus kepedulian 
sosialnya, sekarang para pemuda tarekat kini diwadahi dalam sebuah lembaga bernama Mahasiswa Ahlith Thariqah alMu'tabarah Annahdliyyah (Matan).(44)

Adanya suatu naungan tersebut para remaja pemudapemudi diharapkan memiliki kemampuan intelektual yang baik, memiliki peningkatan kualitas ibadah, jauh dari penyakit hati, patuh dan taat kepada Allah Swt, Rasulullah Sawdan guru-guru mursyid termasuk pimpinan negara, serta khidmat kepada umat dan bangsa.Selain itu ajaran tarekat sangat relevan apabila diterapkan pada generasi muda saat ini. Tarekat bisa menjadi solusi bagi generasi muda dalam mengarungi hidup pada era globisasi yang serba bebas dan pergerakan arus informasi yang terbuka luas ini. Sebab, tarekat tidak lepas dari zikir dan bimbingan para guru mursyid.(44)

b. Kontribusi Bidang Sosial

Kontribusi dari tarekat Junaidi Al-Baghdadi bidang sosial merupakan kontribusi yang tidak hanya bermanfaat bagi para jamaah akan tetapi juga bermanfaat untuk kepentingan sosial yaitu kepentingan bersama untuk kemaslahatan.Jamaah tarekat kini lebih banyak terlibat ke penguatan ekonomi dan sosial dalam bermasyarakat dan berbangsa. (44)

Selain urusan beribadah tarekat ini juga mengimbanginya dengan gerakan-gerakan sosial, tarekat Junaidi Al-Baghdadi dalam kontribusinya pada bidang sosial adalah dengan rencana pembangunan masjid dan pondok pesantren dan pengerjaannya sudah berjalan yang beralamat di jalan Marang, kelurahan Marang, kecamatan Bukit Batu, Palangka Raya. Alasan dibangunnya sebuah pondok dan masjid tersebut adalah karena memang amanat pesan terakhir dari K.H Muhammad Qurtbi Khalid sebagai khalifah pada saat itu, kemudian selain dari amanat pembangunan itu juga ditujukan untuk anak-anak masyarakat di sana guna memberikan pendidikan yang berbasis agama, serta tempat itu nantinya juga akan dijadikan untuk riyadhah. (21)

Majelis Darul Ikhlas sebagai pengembangan dari tarekat Junaidi Al-Baghdadi ini juga memudahkan bagi para jamaah yang apabila ada keluarganya yang meninggal dunia atau salah satu jamaah yang meninggal maka disediakan pemakaman yang memang dibeli sebagai tanah Pemakaman Khusus Jamaah Tarekat Junaidi Al-Baghdadi. Tanah pemakaman itu terletak di Jalan Bangaris. (20)

3. Tarekat Junaidi Al-Baghdadi Terhadap Pembinaan Masyarakat Islam di kota Palangka Raya

Untuk menjawab pertanyaan bagaimana eksistensi tarekat Junaidi Al-Baghdadi maka yang perlu kita pertanyakan adalah bagaimana strategi dari para jamaah Majelis Darul Ikhlas untuk mempertahankan tarekat Junaidi Al-Baghdadi tersebut untuk menjadi tarekat yang mereka gunakan. Strategi yang dipakai untuk mempertahankan eksistensi tarekat Junaidi Al-Baghdadi pada Majelis Darul Ikhlas yaitu dengan mengikuti perkembangan zaman seperti pengumuman bahwa akan diadakan kegiatan pembelajaran melalui handphone, pembelajaran yang dilakukan tidak mengganggu aktivitas lainnya terutama aktivitas bekerja. Kemudian terjalinnya interaksi yang dilakukan guru dan jamaah, interaksi jamaah kepada jamaah lain dan interaksi antara jamaah kepada masyarakat lain sehingga menimbulkan ketertarikan masyarakat untuk bergabung ke tarekat Junaidi Al-Baghdadi. Dengan adanya interaksi sosial tersebut maka 
terjawablah bagaimana solidaritas yang dibangun oleh jamaah majelis Darul Ikhlas. (20)

Menurut sudut pandang penulis, kesimpulan mengenai tarekat Junaidi Al-Baghdadi ini mengalami perkembangan dan tetap eksis di masyarakat dengan melihat adanya perkembangan berupa pembangunan majelis yang bernama Darul Ikhlas, pembangunan masjid Sirajul Jama'ah sebagai tempat beribadah masyarakat dan tempat belajar, hal ini berarti bahwa pembentukan tersebut karena adanya kebutuhan masyarakat untuk mencari ilmu dengan bertarekat dan juga karena dipengaruhi oleh kian bertambahnya kuantitas dari jamaah tarekat Junaidi Al-Baghdadi.

a. Majelis Darul Ikhlas

Berdasarkan data dari Kementerian Agama Republik Indonesia yang menghimpun datadata majelis yang ada di Kalimantan Tengah bahwa Majelis Darul Ikhlas ini telah terdaftar di Kementerian Agama yang beralamat di Jalan Bukit Rawi, Palangka Raya. Majelis Darul Ikhlas ini menjadi salah satu dari 246 majelis yang ada di Kalimantan Tengah, yang mana majelis Darul Ikhlas ini berdiri pada tahun 2002, dengan status tanah wakaf.(29) Hal tersebut senada dengan pernyataan dari salah satu narasumber yang merupakan pendiri dari Majelis Darul Ikhlas ini, yang mana beliau ini sudah berada di Palangka Raya pada tahun 1973 tepatnya 17 Agustus 1973.(23) Setelah satu tahun kemudian yakni pada tahun 2003 dibangunlah masjid sebagai tempat pembelajaran, masjid itu diberi nama Sirajul Jama'ah.

Guru yang pernah mengajar dan yang masih mengajar di Majelis Darul Ikhlas ini yaitu (Alm) Guru Abdul Wahab, (Alm) Guru Kursani, (Alm) Guru Norman. Untuk yang sekarang mengajar di Majelis Darul Ikhlas ini adalah Guru Abdul Fattah. Pembelajaran dilakukan tiga kali seminggu yaitu Senin, Rabu dan Kamis. Jumlah jamaah majelis Darul Ikhlas ini kurang lebih 40 orang yang terdiri dari laki-laki dan perempuan. (23)

Sebelumnya telah disinggung sedikit mengenai amaliyah melalui sholawat melalui qasidah ataupun syair habsyi, yang mana para jamaah berkumpul sekitar jam 08.00 pagi, transportasi yang digunakan adalah menggunakan angkutan kota (angkot) untuk pergi ke Jalan Bukit Rawi ada juga yang menggunakan transportasi pribadi seperti sepeda motor.

Tarekat Junaidi Al-Baghdadi ini terdapat 3 tingkatan panggilan dalam kepengurusannya yang mana dalam menentukan siapasiapa orang yang akan menduduki tersebut tidak bisa sembarang yakni harus mencapai Riyadhah, untuk tingkatan tersebut yaitu:(23) Khalifah (Pucuk Pimpinan), Khalif (Perwakilan) dan Badal (Ganti). Juga terdapat 3 tingkatan tarekat juga, yaitu:(31) Tarekatul Ula (riyadhahnya sugro), Tarekatul Wushto (riyadhahnya qubro) dan Tarekatul Qushwa wal Ulya (riyadhahnya gaiyah).

Untuk syarat masuk dalam jamaah tarekat Junaidi AlBaghdadi pada majelis Darul Ikhlas ini tidak berbelit-belit, setidaknya hanya ada dua yaitu jangan ada paksaan (harus karena gerakan hati sendiri) dan mau mengamalkannya setelah belajar. Selain itu adapun syarat untuk umur adalah perempuan berumur 18 tahun dan laki-laki berumur 20 tahun. Setelah mengetahui syaratnya maka selanjutnya yang dilakukan adalah pembaiatan serta saat mempelajari ilmu-ilmu tersebut ada yang dinamakan khataman. (31)

Tata cara atau prosesi baiat dalam tarekat Junaidi Al- 
Baghdadi pada Majelis Darul Ikhlas ini yaitu guru dan murid atau calon murid saling berhadapan sama-sama memegang satu tasbih yang dipegang setengahnya antara jamaah dan guru (badal). Mata guru berpejam, sementara mata murid atau calon murid yang ingin berbaiat tersebut tidak boleh menutup hal itu berfungsi untuk memperhatikanguru agar adanya kesamaan dalam gerakan menaik turunkan nafas dengan beristigfar serta menyebut Allah. Agar gerakan hembusan (menaik turunkan) nafas sama maka guru akan memberikan kode dengan menarik tasbih yang sama-sama dipegang tadi.(31)Tata cara atau prosesi baiat dalam tarekat Junaidi Al-Baghdadi pada Majelis Darul Ikhlas ini yaitu guru dan murid atau calon murid saling berhadapan sama-sama memegang satu tasbih yang dipegang setengahnya antara jamaah dan guru (badal). Mata guru berpejam, sementara mata murid atau calon murid yang ingin berbaiat tersebut tidak boleh menutup hal itu berfungsi untuk memperhatikanguru agar adanya kesamaan dalam gerakan menaik turunkan nafas dengan beristigfar serta menyebut Allah. Agar gerakan hembusan (menaik turunkan) nafas sama maka guru akan memberikan kode dengan menarik tasbih yang sama-sama dipegang tadi. (31)

Untuk khataman terbagi menjadi enam yaitu Khatam 10 Muharram, Khatam 12 Rabiul Awwal, Khatam 27 Rajab, Khatam Nisfu Sya'ban, Khatam 17 Ramadhan, Khatam 9 Dzulhijjah.

b. Majelis Dalail Al-Karamah Tarekat Junaidi Al-Baghdadi di Palangka Raya selain Majelis Darul Ikhlas, majelis ini membuat cabang sebagai tempat untuk berdalail atau sekedar yasinan dan bersholawat yang bernama Majelis Dalail Al-Karamah bertempat di Jalan Rindang Banua.

Majelis Dalail Al-Karamah ini berfungsi sebagai wadah untuk para jamaah berkumpul apabila ada jamaah yang lain terkena musibah seperti halnya ada salah satu jamaah atau keluarga jamaah yang meninggal maka para jamaah yang lain berkumpul untuk datang melawat. Kegiatan selain itu adalah setiap malam yang sudah ditentukan dan disepakati maka akan diadakan pembacaan burdah.(36)

Guru atau ustaz yang mengajar pada majelis Dalail AlKaramah ini sama pada majelisDarul Ikhlas yaitu guru $\mathrm{H}$. Abdul Fatah. Yang membedakan antara majelis Darul Ikhlas dan majelis Dalail Al-Karamah ini yaitu:

1. Majelis Darul Ikhlas membahas mengenai tarekat, makrifat, fikih, tauhid, sementara majelis Dalail AlKaramah membahas hal yang lebih ringan seperti yasinan dan sholawat

2. Majelis Darul Ikhlas resmi terdaftar dan tercatat pada Kementerian Agama Republik Indonesia, sementara majelis Dalail Al-Karamah masih belum terdaftar secara resmi

3. Majelis Darul Ikhlas didirikan memang untuk belajar tarekat, sedangkan majelis Dalail AlKaramah terdiri dari kumpulan-kumpulan orang yang ikut tarekat namun khusus untuk jamaah tarekat yang berdomisili di Jalan Rindang Banua.

4. Kegiatan yasinan majelis Dalail Al-Karamah bertempat di rumah para anggota atau jamaah dengan sistem rolling (secara bergantian).(22) 


\section{Kesimpulan}

Sejarah berdirinya tarekat Junaidi alBaghdadidimulai dari penyebaran agama Islam melalui proses Islamisasi hingga dapat membaur dan diterima di Palangka Raya sehingga sampailah kepada penyebaran tarekat Junaidi Al-Baghdadi ini yang dibawa oleh (Alm) Guru Kasful Anwar langsung dari Mekkah, yang kemudian beliau percayakan kepada murid beliau yang benama (Alm) H, Muhammad Qurtbi Khalid yang pada awalnya disangka orang adalah penyebar tarekat yang sesat sehingga tarekat ini sempat beberapa waktu vakum (berhenti sementara). Kemudian sistem pembinaan yang digunakan Majelis Darul Ikhlas untuk mempelajari tarekat Junaidi Al-Baghdadi ini yaitu klasikal tradisional, ceramah tanya jawab, dan materi serta amalan yang digunakan untuk kehidupan sehari-hari. Untuk melihat bagaimana perkembangan tarekat Junaidi Al-Baghdadi ini sendiri dapat dilihat dari perkembangan kuantitas para jamaah yang bertambah, hingga kemudian dapat berdirinya Majelis Darul Ikhlas dan Majelis Dalail Al-Karamah sebagai tempat dari pembelajaran para jamaah pengikut tarekat Junaidi Al-Baghdadi.

Berdasarkan penelitian ini, terdapat beberapa saran yaitu pendataan para jamaah ditingkat para badal-badal hendaknya lebih dilakukan karena agar memudahkan dalam data pribadi para jamaah sehingga tersampaikan juga siapa saja para jamaah yang baru berbaiat atau yang ingin bergabung masuk tarekat ini kepada tingkatan khalif dan khalifah dari tarekat ini, yang mana akan menjadikan tarekat ini lebih terstruktur lagi. Perlu adanya sosialisasi kembali mengenai kepengurusan tarekat ini sehingga orang awam atau orang yang ingin meneliti ini dapat mudah melihat jejak-jejak tarekat Junaidi AlBaghdadi ini, perlu adanya penelitian lanjutan yang lebih mendalam tentang tarekat Junaidi Al-Baghdadi di Kota Palangka Raya.

Peneliti mengakui bahwa penelitian ini bukanlah hasil akhir yang bersifat mutlak. Peneliti juga mengakui bahwa tidak menutup kemungkinan bagi peneliti lain dapat memperoleh hasil yang lebih atau berbeda dari peneliti. Untuk itu, lakukanlah penelitian lebih lanjut terhadap tarekat Junaidi AlBaghdadi ini guna memperoleh hasil yang lebih dari peneliti. Terakhir dari peneliti, demi mewujudkan harapan kita bersama, pelajari dan jadilah pribadi yang inklusif dalam hal beragama demi mewujudkan kedamaian dunia.

\section{Daftar Pustaka}

1. Abdel-Kader DAH. Imam Al-Junaid Al-Baghdadi Pemimpin Kaum Sufi. Yogyakarta: Diva Press, 2018.

2. Abdillah A. Argumen ahlussunnah wal jama'ah: jawaban tuntas terhadap tudingan bid'ah dan sesat. Pustaka Ta'awun, 2011.

3. Abuddin Nata. Perspektif Islam Tentang Strategi Pembelajaran. Jakarta: Kencana, 2009.

4. Achada MY. Sejarah Dan Perkembangan Pondok Pesantren Darut Tauhid Al-Alawiyyah Potroyudan Jepara Jawa Tengah 19802016. Fakultas Adab dan Humaniora UIN Syarif Hidayatullah, 2017.

5. Ahmad Chodjim. Alfatihah: Membuka Matahari Dengan Surat Pembuka. Jakarta: PT. Serambi Ilmu Semesta, 2003.

6. Ahmad Zain. Kekuatan Istighfar: Istighfar Mengahapus Dosa. Puskafi:

Pusat Kajian Fikih dan Ilmu-ilmu KeIslaman:

7. Alhafiz K. Syekh Junaid Al-Baghdadi, Imam Tasawuf Panutan NU. NU: 2018.

8. Amin SM. Energi Dzikir : Menentramkan Jiwa Membangkitkan Optimisme. 1st ed. Amzah, 2008.

9. Amin Syukur, Fathimah. Insan Kamil, Paket Pelatihan Seni Menata Hati (SMH) Lembkota. Semarang: CV. Bima Sakti, 2006.

10. Anshori MS. Filsafat Islam : antara ilmu dan kepentingan. 2011.

11. Armah. Wawancara. 2019.

12. Azra A. Renaisans Islam Asia Tenggara: Sejarah Wacana \& Kekuasaan. Remaja Rosdakarya, 1999. 
13. Azra A. Jaringan ulama: Timur Tengah dan kepulauan Nusantara abad XVII \& XVIII : akar pembaruan Islam Indonesia. Jakarta: Kencana, 2004.

14. Daradjat Z. Perbandingan agama, buku 1. Direktorat tsb., 1983.

15. Dedi Supriadi. Fiqih Bernuansa Tasawuf Al-Ghazali Perpaduan Antara Syari'at dan Hakikat. Bandung: Pustaka Setia, 2008.

16. Emzir. Analisis Data: Metodologi Penelitian Kualitatif. Jakarta: Rajawali Pres, 2011.

17. Fitriana E. Pola Keruangan Budaya Oloh Salam Masyarakat Kalimantan Tengah dengan Pendekatan Geospasial. JURNAL GEOGRAFI 10: 74-85, 2018.

18. Fousiah Dwi Astuti. Konsep Wirid Qur'ani (Studi Atas Kitab Al-Ma'surat Karya Hasan Al-Bana). Yogyakarta: 2013.

19. George Ritzer, Douglas J. Goodman. Teori Sosiologi Modern. Jakarta: Kencana Prenada Media Group, 2007.

20. H.Abdul Fatah. Wawancara. 2019.

21. Hj.Imas. Wawancara. 2019.

22. Hj.Norsehan. Wawancara. 2019.

23. H.Suryani. Wawancara. 2019.

24. Husnul Khotimah. Aktivitas Dakwah Islam Tarekat Junaidi Al-Baghdadi Palangka Raya. Skripsi S1, Palangka Raya: Sekolah Tinggi Agama Islam Palangka Raya: 2005.

25. Indonesia. Pengantar Ilmu Tasawuf. Medan: Proyek Binpertais, 1982.

26. Ipansyah N. Tarekat Junaidiyah Di Kalimantan Selatan. Al-Banjari 10, 2017.

27. Ivan Aulia Ahsan. Junaid al-Baghdadi, Ulama Tasawuf Panutan Kaum Nahdliyin. Tirto: 2019.
28. Karuniawati AT. Sejarah Tarekat Muqtadiriyah Di Sidoarjo Tahun 2006 - 2011. UIN Sunan Ampel Surabaya: 2015.

29. Kementerian Agama Republik Indonesia. Data Majelis Taklim Simpenais. [date unknown].

30. Masburiyah. Konsep Dan Sistmatika Pemikiran Fiqih Sufistik Al-Ghazali. Nalar Fiqh: Jurnal Kajian Ekonomi Islam dan Kemasyarakatan 3, 2011.

31. Nur Jannah. Wawancara. 2019.

32. Riyadi A. Tarekat Sebagai Organisasi Tasawuf (Melacak Peran Tarekat Dalam Perkembangan Dakwah Islamiyah). At-Taqaddum 6: 359-385, 2016.

33. Sagala S. Konsep dan makna pembelajaran untuk membantu memecahkan problematika belajar dan mengajar / oleh Syaiful Sagala. Cet. 7. Alfabeta, 2009.

34. Salim P. Kamus bahasa Indonesia kontemporer. Modern English Press, 2002.

35. SARDIMAN AM. Interaksi \& motivasi belajar mengajar. RajaGrafindo Persada, 2007.

36. Siti Fatimah. Wawancara. 2019.

37. Slamet Santoso. Dinamika kelompok edisi revisi. Jakarta: Bumi Aksara, 2009.

38. Suciati. Teori belajar dan motivasi / Suciati, Prasetya Irawan. PAU-PPAI Universitas Terbuka, 2001.

39. Sugiyono. Metode Penelitian Kuantitatif, Kualitatatif, dan $R \& D$. Bandung: Alfabeta, 2016.

40. Sunanto M. Sejarah peradaban Islam Indonesia. Divisi Buku Perguruan Tinggi, RajaGrafindo Persada, 2005. 
41. Taneko SB. Struktur dan proses sosial: suatu pengantar sosiologi pembangunan. Rajawali, 1984.

42. Taofik Ridwan. Sejarah Peradaban Islam. Jakarta: Arafah Mitra Utama, 2008.

43. Usman MI. Model Mengajar Dalam Pembelajaran: Alam Sekitar, Sekolah Kerja, Individual, Dan Klasikal. Lentera Pendidikan: Jurnal Ilmu Tarbiyah dan Keguruan 15: 251-266, 2012.

44. Wachidah. Generasi Muda Minati Ajaran Thariqa. Republika, 2016.
45. Wina Sanjaya. Strategi Pembelajaran Berorientasi Standar Proses Pendidikan. Jakarta: Kencana, 2008.

46. Yani Z. Tarekat Sammaniyah Di Palembang. Tamaddun: Jurnal Kebudayaan dan Sastra Islam 14: 1938, 2014.

47. Zuhdi Z. Afiliasi Mazhab Fiqh Tarekat Shâdhilîyah di Jombang. TEOSOFI:

Jurnal Tasawuf dan Pemikiran Islam 4: 1-28, 2014.

48. Zulmi M. A. Tarekat Qodariyah Wa Naqsabandiyah Syaikhona Muhammad Kholil Bangkalan Tahun 1834-1925 . Avatara 1, 2013. 